\title{
Banana fertigation with treated sanitary wastewater: postharvest and microbiological quality
}

\section{Fertirrigação da bananeira com água residuária sanitária tratada: qualidade pós-colheita e microbiológica}

\author{
Pablo Fernando Santos Alves ${ }^{1 *}$; Silvânio Rodrigues dos Santos ${ }^{2}$; \\ Marcos Koiti Kondo ${ }^{2}$; Gisele Polete Mizobutsi²; Luciana Albuquerque Caldeira²; \\ Igor Santos Alves ${ }^{3}$; Alciane Batista Antunes ${ }^{4}$; Gilberto Felipe de Oliveira ${ }^{5}$
}

\begin{abstract}
Sewage may serve as a source of water and nutrients for plants. In this study, the effects of fertigation with treated sanitary wastewater from Janaúba Sewage Treatment Plant were evaluated on the postharvest and microbiological quality of 'Prata-Anã' banana. A randomized block experimental design was used. Four concentrations of wastewater were tested (70, 130, 170, and $200 \%$ of $150 \mathrm{~kg} \mathrm{ha}^{-1}$ sodium). A wastewater-free control treatment was used for comparison. Two crop cycles were assessed for postharvest and microbiological quality. The parameters measured included total soluble solids, titratable acidity, total soluble solids/titratable acidity ratio, $\mathrm{pH}$, total coliforms, and fecal coliforms on both the peel and the pulp. In the first crop cycle, both soluble solids and fruit pulp pH decreased as wastewater level increased up to a maximum of $141.5 \%$. These correlations were not observed in the second cycle. Wastewater management did not affect the titratable acidity of the soluble solids. The agricultural application of treated sanitary wastewater provided banana fruits with a microbiological profile similar to that obtained with the control (pure water) and with mineral fertilizers. A microbial balance is necessary to maintain the nutritional status of the banana crop.
\end{abstract}

Key words: Musa spp. Agricultural wastewater reuse. Environmental sanitation.

\section{Resumo}

A utilização de água residuária proveniente do tratamento de esgoto, como fonte hídrica e nutricional para as plantas, é uma alternativa para racionalizar o aproveitamento do recurso natural na agricultura. O objetivo desse trabalho foi avaliar os efeitos da aplicação da água residuária sanitária de tratamento secundário da Estação de Tratamento de Esgoto de Janaúba - MG sobre a qualidade pós-colheita e microbiológica da bananeira 'Prata-Anã'. O experimento foi conduzido no delineamento de blocos casualizados. As doses de água residuária testadas foram equivalentes a 70, 130, 170 e $200 \%$ do limite máximo de $150 \mathrm{~kg} \mathrm{ha}^{-1}$ sódio que pode ser aportado ao solo. Para efeito de comparação foi conduzido também um tratamento testemunha, irrigado com água limpa. Durante dois ciclos produtivos da cultura determinaram-se os seguintes atributos pós-colheita da banana: sólidos solúveis totais, acidez total

\footnotetext{
${ }^{1}$ Discente, Programa de Pós-Graduação em Produção Vegetal no Semiárido, Universidade Estadual de Montes Claros, PPGPVSA, UNIMONTES, Janaúba, MG, Brasil. E-mail: agrotecnico10@yahoo.com.br

2 Profs., Departamento de Ciências Agrárias, UNIMONTES, Janaúba, MG, Brasil. E-mail: silvanio.santos@unimontes.br; marcos. kondo@unimontes.br; gisele.mizobutsi@unimontes.br; luciana.caldeira@unimontes.br

3 Discente, Programa de Pós-Graduação em Produção Vegetal, Universidade Federal dos Vales do Jequitinhonha e Mucuri, PPGPV-UFVJM, Diamantina, MG, Brasil. E-mail: igors.agro@gmail.com

${ }^{4}$ Discente, Curso de Zootecnia, UNIMONTES, Janaúba, MG, Brasil. E-mail: alcianebatista@hotmail.com

${ }^{5}$ Discente, Curso de Agronomia, UNIMONTES, Janaúba, MG, Brasil. E-mail: gilbertocarrasco1@hotmail.com

* Author for correspondence
} 
titulável, relação sólidos solúveis totais/acidez titulável e o pH. Para a análise microbiológica foram coletados frutos em cada ciclo produtivo da cultura, quando se quantificou a presença de coliformes totais e coliformes termotolerantes na casca e na polpa das bananas. No primeiro ciclo de produção da bananeira, o teor de sólidos solúveis dos frutos decresce com o aumento no aporte de água residuária sanitária tratada até o limite de $141,5 \%$, havendo também redução do $\mathrm{pH}$ dos frutos, porém, tal fenômeno não é verificado no segundo ciclo. A relação sólidos solúveis:acidez titulável e a acidez titulável não são influenciadas pelo manejo com água residuária sanitária tratada. Considerando o grupo de microrganismos avaliados e tendo em vista a manutenção do equilíbrio do estado nutricional da cultura, o reúso agrícola da água residuária sanitária tratada permite a obtenção de frutos de banana com qualidade microbiológica semelhante àqueles obtidos pelo manejo com água limpa e fertilizantes minerais.

Palavras-chave: Musa spp. Reúso agrícola de efluentes. Saneamento ambiental.

\section{Introduction}

One of the determining factors for success in fruit growing is fruit quality, the criteria for which are largely determined by consumer demands.

According to Chitarra and Chitarra (2005), the main physiological characteristics correlated to fruit quality that influence fruit preferences are $\mathrm{pH}$, titratable acidity, soluble solids, ratio between soluble solids and acidity, reducing sugars, nonreducing sugars, total sugars, pectic substances, and starch content.

According to Maia et al. (2003), the relationship between fertilization and banana production has been extensively studied but the relationship between fertilization and fruit quality has received far less attention. Nevertheless, Silva et al. (1999) reported that fertilizer application rate is a preharvest factor directly correlated with banana quality. Therefore, the effects of crop fertilization using unconventional sources like sewage effluents (in the form of treated wastewater) must be closely monitored to ensure that they do not compromise product quality or consumer acceptance.

Despite advances in sewage treatment processes, most wastewater sources still contain large amounts of microbes that are potentially harmful to consumers and rural workers (SHUVAL et al., 1997; SCANDOLERA et al., 2001; METCALF; EDDY, 2003; BARKER et al., 2014). Al-Lahham et al. (2003) studied the quality and contamination levels of tomato fruit produced with wastewater.
Paganini (2003) argues that applying sewage waste to the soil for irrigation or any other use involving the soil-plant system creates an immediate and direct risk of microbial contamination. This risk is further increased by sprinkler irrigation, which puts the vegetation to be consumed in direct contact with the sewage waste. The author points out that microorganisms (including pathogens) generally survive for a shorter period of time on crop surfaces than in soil and water. Nevertheless, the microbes could be deposited on crowns, cracks, stems, and stalks where they would be protected from adverse environmental conditions such as solar irradiation, high temperatures, and desiccation until harvest. In this way, the crop could be rendered unfit for human consumption.

In general, field crops may be contaminated by pathogens like Salmonella spp., Shigella spp., Campylobacter spp., Escherichia coli, Staphylococcus aureus, Clostridium botulinum, Bacillus cereus, Vibrio spp., Hepatitis A virus, and Norovirus. They could also be infested with pathogenic fungi and the parasites Cryptosporidium and Cyclospora, as well as the eggs of other intestinal parasites like Taenia solium (VUGIA et al., 2002).

The objective of this work was to evaluate the post-harvest and microbiological quality of the fruit of 'Prata-Anã' banana plants irrigated with treated sanitary wastewater. 


\section{Materials and Methods}

This work was carried out in the experimental area of the Sewage Treatment Station (STS) of the Minas Gerais Sanitation Company, COPASA - MG in Janaúba-MG, located at $15^{\circ} 49^{\prime} 53^{\prime \prime} \mathrm{S}$ and $43^{\circ} 16^{\prime}$ 20 "W at an altitude of $540 \mathrm{~m}$. According to Köppen, the climate is Aw (tropical, with dry winter).
The soil in the experimental area is classified as a eutrophic Red Latosol (EMBRAPA, 2013). The soil physical and chemical properties before banana orchard planting and fertigation experiment are shown in Table 1.

Table 1. Mean soil physical and chemical properties for a eutrophic Red Latosol, before fertigation experiment.

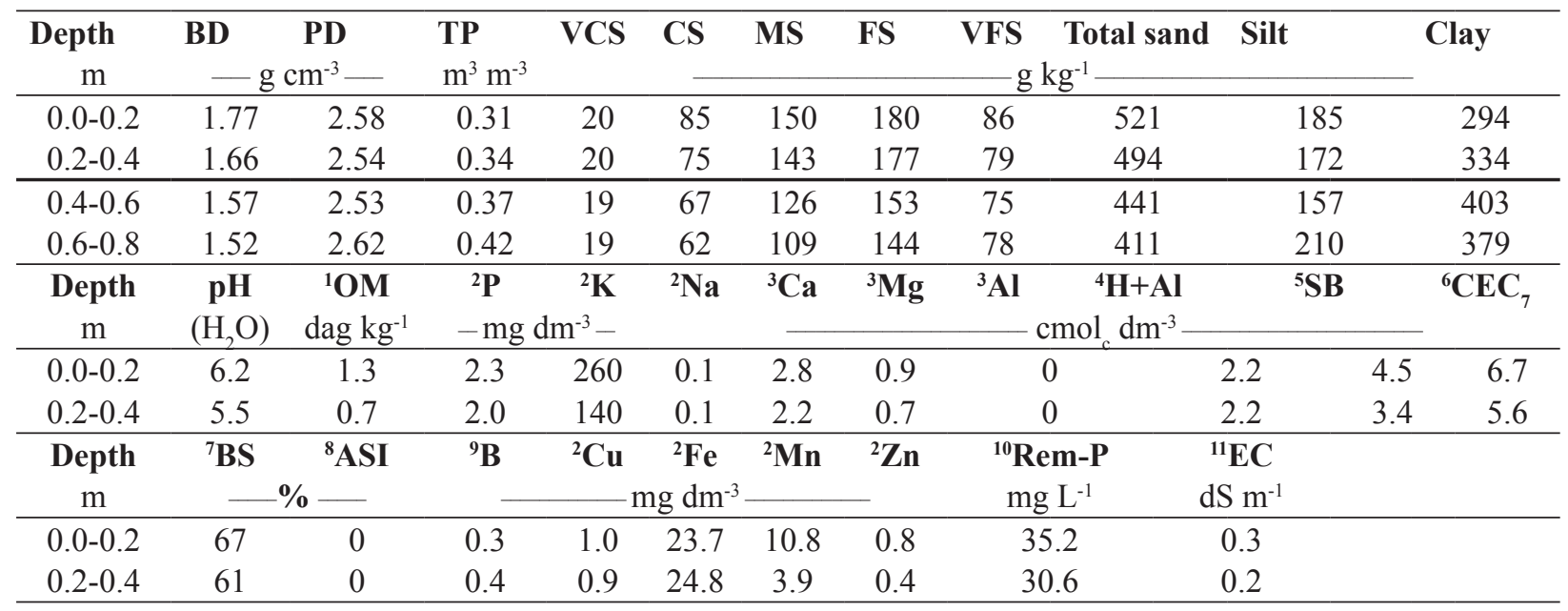

BD: soil bulk density; PD: particle soil density; TP: total porosity; VCS: very coarse sand; CS: coarse sand; MS: medium sand; FS: fine sand; VFS: very fine sand; ${ }^{1}$ Organic matter, colorimetric method; ${ }^{2}$ Mehlich-1 extractor; ${ }^{3} \mathrm{KCl} 1 \mathrm{~mol} \mathrm{~L}{ }^{-1} \mathrm{extractor} ;{ }^{4} \mathrm{pH}$ SMP method; ${ }^{5} \mathrm{SB}$ : sum of bases; ${ }^{6} \mathrm{CEC}_{7}$ : cation exchange capacity at $\mathrm{pH} 7$; ${ }^{7} \mathrm{BS}$ : base saturation; ${ }^{8} \mathrm{ASI}$ : aluminium saturation index; ${ }^{9} \mathrm{BaCl}_{2}$ extractor; ${ }^{10}$ remaining phosphorus in the equilibrium solution; ${ }^{11} \mathrm{EC}$ : electrical conductivity of the saturated paste extract, 1:0.5 soil/water ratio.

The experimental design was a randomized block with four replications. The treatments consisted of different doses of treated wastewater (TWW) from the STS. The maximum annual application limit (AML) for the soil was $150 \mathrm{~kg} \mathrm{ha}^{-1}$ sodium (Na) (LARCHER, 2005). The treatments were: T1 - control (clean water + mineral fertilization); T2 $-70 \%$ TWW; T3 - 130\% TWW; T4 - 170\% TWW, and T5 $-200 \%$ TWW (relative to the reference AML).

The sewage treatment system of the Janaúba STS consists of a preliminary treatment (grille and desander), a Parshall gauge with an ultrasonic flow meter, an anaerobic upflow reactor (UASB), a facultative lagoon, and two maturation ponds in series, with a continuous flow rate capacity of up to $48.4 \mathrm{~L} \mathrm{~s}^{-1}$.

The banana plant cultivar 'Prata-anã' was planted on $05 / 05 / 2012$ as micropropagated seedlings on a 3 x $2 \mathrm{~m}$ plot. There were four rows of six plants per line for a total of twenty-four plants per plot.

Fifteen days prior to planting, the foundation was fertilized in the aforementioned planting rows by mixing soil with a 4-30-10 NPK formulation, single superphosphate, and FTE BR12. The target nutrient concentrations were $22.8 \mathrm{~kg} \mathrm{ha}^{-1} \mathrm{~N}, 200.0$ $\mathrm{kg} \mathrm{ha}^{-1} \mathrm{P}_{2} \mathrm{O}_{5}, 50.0 \mathrm{~kg} \mathrm{ha}^{-1} \mathrm{~K}_{2} \mathrm{O}, 48.6 \mathrm{~kg} \mathrm{ha}^{-1} \mathrm{~S}, 103.9$ $\mathrm{kg} \mathrm{ha}^{-1} \mathrm{Ca}, 1.5 \mathrm{~kg} \mathrm{ha}^{-1} \mathrm{~B}, 0.7 \mathrm{~kg} \mathrm{ha}^{-1} \mathrm{Cu}, 1.7 \mathrm{~kg} \mathrm{ha}^{-1}$ $\mathrm{Mn}, 0.1 \mathrm{~kg} \mathrm{ha}^{-1} \mathrm{Mo}$, and $7.5 \mathrm{~kg} \mathrm{ha}^{-1} \mathrm{Zn}$. 
TWW applications were done weekly through the irrigation system (micro-sprinkling) starting 41 days after planting (DAP). After each TWW application, water was added to meet crop requirements. By the third month of planting, chemical fertilization was started in the form of nitrogen and potassium surface fertigation in the control and complementation of all treatments with the application of effluents. Similar doses were applied to all plots in the attempt to balance the nutrient supply.

Irrigation rates were determined on the basis of the evapotranspiration rate of the crop and were calculated from the daily reference evapotranspiration $\left(\mathrm{ET}_{0}-\right.$ Penman-Monteith method) (ALLEN et al., 2006), the crop coefficient (OLIVEIRA et al., 2005), the location coefficient, and the sensitivity to soil water deficit coefficient (MANTOVANI et al., 2009). The soil moisture was monitored every two weeks at the effective root system depth $(0.6 \mathrm{~m})$. Adjustments in application depth were made accordingly. All other parameters followed the recommendations for the crop.

On a monthly basis, TWW samples were collected during applications for the analysis of biological and physicochemical parameters (APHA et al., 2012). TWW application depth was calculated in the respective treatments on the basis of the results of this analysis from the previous month. Table 2 shows the average chemical composition of the major wastewater constituents during the experimental period.

Tables 3 and 4 show the major wastewater constituents and nutrients added to the soil via fertigation during the first two years of the experiment. The tables also indicate the application depths.

Table 2. Mean values of treated sanitary wastewater characteristics from Janaúba Sewage Treatment Plant, between June 2012 and June 2014, during fertigation experiment.

\begin{tabular}{|c|c|c|c|}
\hline Characteristic & Unit & Mean & Standard Deviation \\
\hline $\mathrm{N}_{\mathrm{t}}$ & $\mathrm{mg} \mathrm{L}^{-1}$ & 47.6000 & $\pm \quad 8.6364$ \\
\hline $\mathrm{N}^{\text {total }}$ & $\mathrm{mg} \mathrm{L}^{-1}$ & 35.7000 & 9.6572 \\
\hline ammon & $\mathrm{mg} \mathrm{L}^{-1}$ & 1.0800 & 1.7207 \\
\hline $\mathrm{N}^{\text {nit }}$ & $\mathrm{mg} \mathrm{L}^{-1}$ & 10.8200 & 8.0942 \\
\hline $\mathrm{K}^{\mathrm{org}}$ & $\mathrm{mg} \mathrm{L}^{-1}$ & 33.9390 & $\pm \quad 11.1534$ \\
\hline $\mathrm{Na}$ & $\mathrm{mg} \mathrm{L}^{-1}$ & 84.3690 & \pm 19.4586 \\
\hline $\mathrm{P}$ & $\mathrm{mg} \mathrm{L}^{-1}$ & 8.2180 & 1.6438 \\
\hline $\mathrm{Zn}^{*}$ & $\mathrm{mg} \mathrm{L}^{-1}$ & 0.0880 & 0.0601 \\
\hline $\mathrm{Cu}$ & $\mathrm{mg} \mathrm{L}^{-1}$ & 0.0080 & 0.0011 \\
\hline $\mathrm{Fe}$ & $\mathrm{mg} \mathrm{L}^{-1}$ & 0.6800 & 0.2875 \\
\hline $\mathrm{Mn}$ & $\mathrm{mg} \mathrm{L}^{-1}$ & 0.1000 & 0.0102 \\
\hline B & $\mathrm{mg} \mathrm{L}^{-1}$ & 0.0230 & 0.0084 \\
\hline $\mathrm{Cl}^{-}$ & $\mathrm{mg} \mathrm{L}^{-1}$ & 130.6000 & $\pm \quad 28.2479$ \\
\hline $\mathrm{Co}$ & $\mathrm{mg} \mathrm{L}^{-1}$ & 0.0010 & 0.0086 \\
\hline $\mathrm{Ca}$ & $\mathrm{mg} \mathrm{L}^{-1}$ & 19.1340 & 4.9072 \\
\hline $\mathrm{Mg}^{*}$ & $\mathrm{mg} \mathrm{L}^{-1}$ & 7.9630 & 3.7786 \\
\hline ECE & $\mathrm{dS} \mathrm{m}^{-1}$ & 1.1280 & 0.1619 \\
\hline $\mathrm{COD}$ & $\mathrm{mg} \mathrm{L}^{-1}$ & 174.8000 & $\pm \quad 35.1715$ \\
\hline BOD & $\mathrm{mg} \mathrm{L}^{-1}$ & 58.8800 & \pm 16.8785 \\
\hline $\mathrm{O} \& \mathrm{G}$ & $\mathrm{mg} \mathrm{L}^{-1}$ & 11.0000 & 4.1227 \\
\hline $\mathrm{pH}$ & & 7.6040 & 0.2467 \\
\hline TSS & $m g L^{-1}$ & 70.2000 & $\pm \quad 33.8934$ \\
\hline $\mathrm{TC}$ & $\mathrm{CFU}(100 \mathrm{~mL})^{-1}$ & $5.01 \mathrm{E}+06$ & $4.32 \mathrm{E}+06$ \\
\hline E. coli & $\operatorname{MPN}(100 \mathrm{~mL})^{-1}$ & $9.60 \mathrm{E}+03$ & $3.16 \mathrm{E}+05$ \\
\hline
\end{tabular}

$\mathrm{N}_{\text {total }}$ : total nitrogen; $\mathrm{N}_{\text {ammo }}$ : ammonia nitrogen; $\mathrm{N}_{\text {nit }}$ : nitrate nitrogen; $\mathrm{N}_{\text {org }}$ : organic nitrogen; $\mathrm{K}$ : potassium; Na: sodium; P: phosphorus; Zn: zinc; Cu: copper; Fe: iron; Mn: manganese; B: boron; $\mathrm{Cl}^{-}$: chloride; Co: cobalt; Ca: calcium; Mg: magnesium; EC: electrical conductivity; COD: chemical oxygen demand; BOD: biochemical oxygen demand; O\&G: oil and grease; TSS: total suspended solids; TC: total coliforms; E. coli: Escherichia coli; *: measured after February 2013. 
Table 3. Nutrients and sodium added to soil with treatments, after two years of banana fertigation with treated sanitary wastewater.

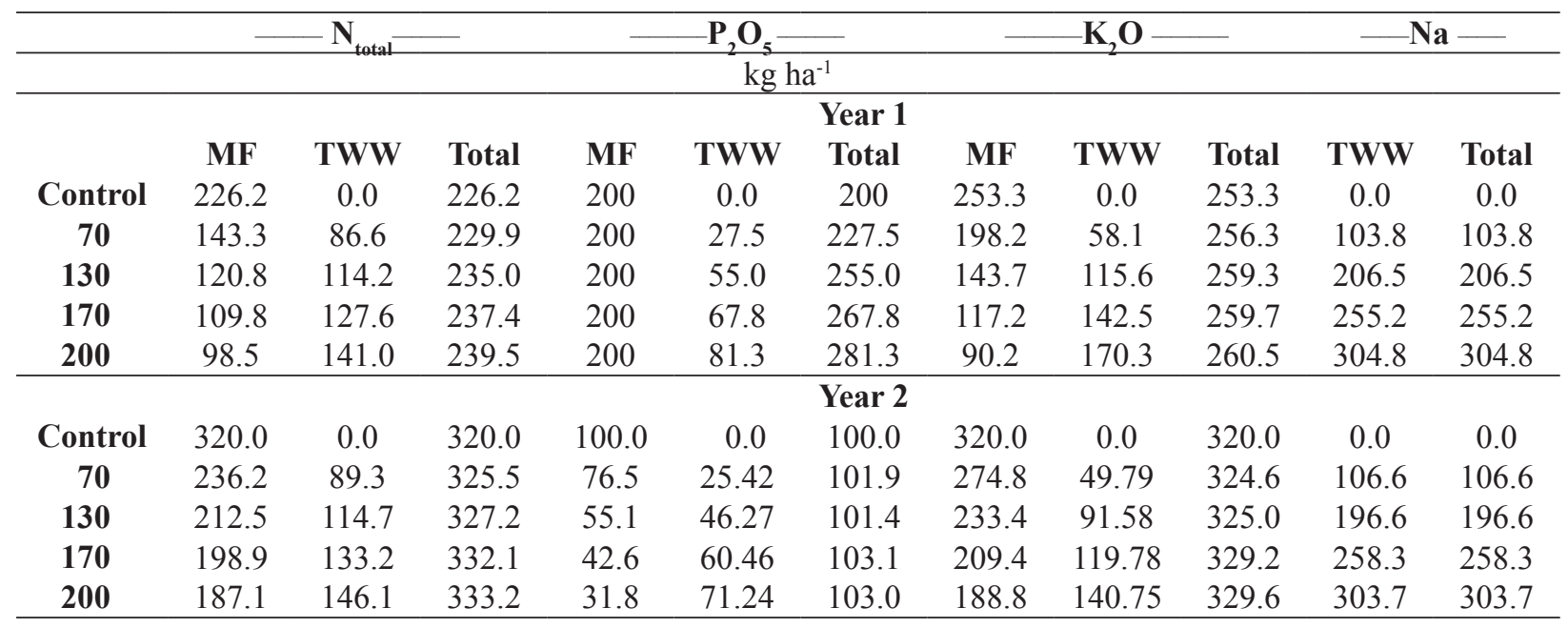

TWW: treated sanitary wastewater; MF: mineral fertilizer; $\mathrm{N}_{\text {total }}$ : total nitrogen provided to banana, $\mathrm{P}_{2} \mathrm{O}_{5}:$ phosphorus; $\mathrm{K}_{2} \mathrm{O}$ : potassium, Na: sodium; Control: potable water and mineral fertilizer top-dressing; 70: 70\%; 130: 130\%; 170: 170\%; 200: 200\% of sodium contribution limit to soil by TWW (150 $\mathrm{kg} \mathrm{ha}^{-1}$ year-1) (LARCHER, 2005).

Table 4. Water depth on experimental plots in two years of the banana plantation with treated sanitary wastewater fertigation.

\begin{tabular}{|c|c|c|c|c|c|c|c|c|}
\hline \multirow[b]{2}{*}{ Treatment } & \multicolumn{3}{|c|}{-Year 1} & \multicolumn{4}{|c|}{$\longrightarrow$ Year 2} & \multirow[b]{2}{*}{ Total } \\
\hline & TWW & Rainfall & SN & Total $\mathbf{m m}$ & TWW & Rainfall & $\mathbf{S N}$ & \\
\hline Control & 0 & 432.8 & 2205.2 & 2638 & 0 & 471.7 & 2010.9 & 2482.6 \\
\hline 70 & 127.1 & 432.8 & 2078.1 & 2638 & 104.14 & 471.7 & 1906.8 & 2482.6 \\
\hline 130 & 252.7 & 432.8 & 1952.5 & 2638 & 190.83 & 471.7 & 1820.1 & 2482.6 \\
\hline 170 & 312.5 & 432.8 & 1892.7 & 2638 & 251.66 & 471.7 & 1759.2 & 2482.6 \\
\hline 200 & 373.4 & 432.8 & 1831.8 & 2638 & 295.71 & 471.7 & 1715.2 & 2482.6 \\
\hline
\end{tabular}

TWW: treated sanitary wastewater; Rainfall: effective rainfall; SN: supplementary net irrigation depth; Total: total irrigation depth applied to experimental plots.

\section{Post-harvest analysis}

Fruit at maturity stage 2 on the Von Loesecke scale (PBMH; PIF, 2006) were harvested to conduct post-harvest analyses. Samples were labeled and taken to the laboratory where they were left on the bench at room temperature until they reached maturation stage 5 on the Von Loesecke scale (PBMH; PIF, 2006).

The following physicochemical parameters were evaluated: (a) total soluble solids (TSS), using an ATAGO model N-1 $\alpha$ field refractometer with a $0-95^{\circ}$ Brix scale; (b) titratable total acidity (TA), determined by titrating $10 \mathrm{~g}$ crushed pulp, homogenizing it in $90 \mathrm{~mL}$ distilled water, and titrating it with $0.1 \mathrm{~N} \mathrm{NaOH}$ solution to which three drops $1 \% \mathrm{w} / \mathrm{v}$ phenolphthalein was added as an indicator. Results were expressed in eq. mg. malic acid per $100 \mathrm{~g}$ pulp according to the standards of the Association of Official Analytical Chemists - AOAC (2012); (c) ratio of total soluble solids/ titratable acidity determined from the percentage of total soluble solids divided by the titratable acidity; (d) $\mathrm{pH}$.

Data were subjected to ANOVA and, when significant, to regression analysis. Treatments were compared to the control using Dunnett's test at 5\% level of significance. Data for the two production cycles were analyzed separately. 


\section{Microbiological analyses}

In the first crop cycle, the fruit was harvested 30 $\mathrm{d}$ and $45 \mathrm{~d}$ after fertigation with the effluent was terminated (DAF). The fruit was collected from the basal, median and apex positions of the bunch at maturity stage 2 on the Von Loesecke scale (PBMH; PIF, 2006). In order to avoid unintentional fruit contamination during the sampling process, the worker would wear clean disposable gloves and make transverse and partial cuts in the pseudostem so the plant would drop slowly. In this way, it could be shored and contact of the fruit with the soil could be prevented.

Since there was no contamination of the fruit from the first cycle, in the second cycle they were collected for microbiological analysis in two lots (06/04/2014 and 06/11/2014), $24 \mathrm{~h}$ after the cessation of wastewater fertigation following the same methodology described previously.

After harvesting, the fruits were placed in sterile plastic bags, labeled, packed in expanded polystyrene boxes, and transported to the laboratory for analysis. For the pulp and peel samples, coliforms (or thermotolerant microorganism) were counted at $35^{\circ} \mathrm{C}$ and $45^{\circ} \mathrm{C}$ using the most probable number
(MPN) method (SILVA et al., 2010). Dilutions were performed by aseptically removing $25-\mathrm{g}$ aliquots from the samples and transferring them to sterile bags containing $225 \mathrm{~mL}$ peptone water; $10^{-2}$ and $10^{-3}$ dilutions were then prepared.

Coliform MPN at $35^{\circ} \mathrm{C}$ was determined by inoculating $1 \mathrm{~mL}$ of $10^{-1}$ sample dilution into test tubes containing inverted Durham tubes immersed in lauryl sulfate tryptose broth. Samples were incubated at $35^{\circ} \mathrm{C}$ for $48 \mathrm{~h}$. To confirm the presence of total coliforms, the positive tubes were immersed in bright green broth.

The presence of coliforms at $45^{\circ} \mathrm{C}$ was confirmed by inoculating broth containing $E$. coli from positive tubes taken from the total coliform analysis and incubating them at $45^{\circ} \mathrm{C}$ for $48 \mathrm{~h}$. Results were expressed as MPN of total coliforms per gram. Data were subjected to descriptive statistical analysis.

\section{Results and Discussion}

Among the attributes evaluated in the postharvest analyses, only total soluble solids (TSS) and $\mathrm{pH}$ were significantly affected by the tested treatments (Table 5).

Table 5. Postharvest characteristics of 'Prata-Anã' banana fruits fertigated with treated sanitary wastewater in two production cycles.

\begin{tabular}{rcccc}
\hline Treatment & TSS $^{\circ}$ brix & TA $^{\mathbf{1}}$ & TSS:TA & pH \\
\cline { 2 - 5 } $\mathbf{7 0}$ & $26.49^{*}$ & First cycle & \\
$\mathbf{1 3 0}$ & 25.60 & 0.52 & 51.23 & 4.61 \\
$\mathbf{1 7 0}$ & 25.23 & 0.50 & 51.77 & $4.57^{*}$ \\
$\mathbf{2 0 0}$ & 26.00 & 0.55 & 46.19 & $4.53^{*}$ \\
Control & $\mathbf{2 5 . 4 5}$ & 0.55 & 48.35 & $4.51^{*}$ \\
\hline $\mathbf{7 0}$ & 26.70 & $\mathbf{0 . 5 1}$ & $\mathbf{4 . 6 7}$ \\
$\mathbf{1 3 0}$ & 25.80 & Second cycle & 4.10 \\
$\mathbf{1 7 0}$ & 25.65 & 0.68 & 4.12 \\
$\mathbf{2 0 0}$ & 26.05 & 0.59 & 39.52 & 4.03 \\
Control & $\mathbf{2 5 . 8 3}$ & 0.69 & 37.87 & 4.05 \\
\end{tabular}

${ }^{1}$ Gram equivalent of malic acid $(100 \mathrm{~g} \text { pulp })^{-1}$. *Mean differ from the control within the cycle, by Dunnett test (p $\left.\leq 0.05\right)$. TSS: Total soluble solids; TA: titratable acidity; TSS: TA: total soluble solids:titratable acidity ratio. 
Table 5 shows that in the first cycle of banana production, the $70 \%$ TWW treatment resulted in a higher TSS content than the control (clean water and conventional fertilization). Regression analysis was performed on this parameter.

In the first crop cycle, TSS was described by a quadratic model (Figure $1 \mathrm{~A}$ ) and decreased up to the TWW dosage equivalent to $141.5 \%$ of the maximum sodium input. From this point to the 200\% TWW dosage, TSS increased slightly with TWW dose but did significantly differ from the control (Table 5).

Increasing TWW up to $141.5 \%$ of the maximum sodium input may have caused imbalances in the soil nutrients, which in turn may have reduced the TSS in the banana fruit. This condition may have been reversed beyond this TWW dose and the nutrient imbalance corrected. Since the banana tree consumes more nitrogen and potassium than any other nutrient (EMBRAPA, 2009), the imbalance caused by the very high TWW doses may have been influenced by them. Weber et al. (2006) examined the effects of nitrogen and potassium fertilization on "Pacovan" bananas and TSS decreases with increasing $\mathrm{N}$ dosage but increases with increasing $\mathrm{K}$ application. Spironello et al. (2004) obtained similar results when testing the effects of NPK fertilization on pineapple fruit production and quality.

Figure 1. A) pH and; B) Total soluble solids (TSS) in banana fruit versus treated sanitary wastewater doses in Janaúba county, Minas Gerais State.

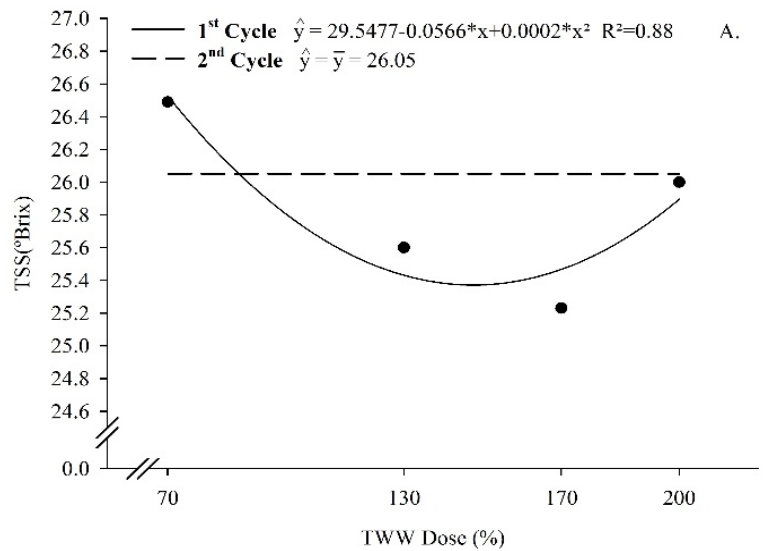

The various TWW doses may have altered the crop cycle so that fruit harvest did not occur at the same developmental stage for all bunches. The application of different TWW doses may have changed the subjective criteria used to determine harvest time such as fruit color and the loss of fruit corners.

The immature (green) banana fruit has high starch content. As it matures (ripens), the starch is broken down into sugars used in respiration. This process

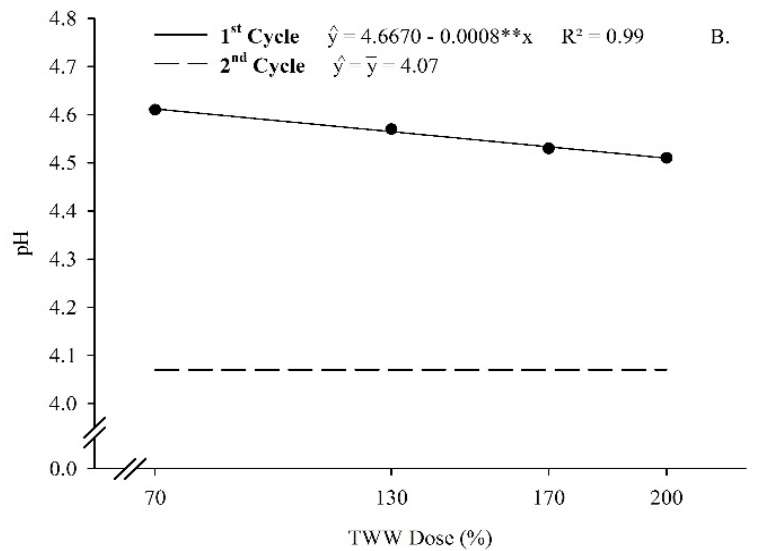

increases the soluble solids content (PIMENTEL et al., 2010). Bleinroth et al. (1992), however, stated that using fruit peel color as the single criterion for the harvest time may not, in fact, indicate the correct maturation point since the peel color changes with solar radiation intensity and water availability.

In the first banana cycle, $130 \%, 170 \%$, and $200 \%$ TWW produced fruit with lower $\mathrm{pH}$ values than those of the control (Table 6). Thus, regression analysis was performed on this parameter and 
indicated that it was best described by a linear model (Figure $1 \mathrm{~B}$ ). It was found that for each percentage unit increase in TWW, the $\mathrm{pH}$ decreased by 0.0008 units.

Differences in the crop cycle may have accounted for the variable TSS as well as differences in banana maturity not perceived at harvest time. Nevertheless, the average TSS values obtained in all treatments lie within the normal range for mature banana fruit (JESUS et al., 2004; VIVIANI; LEAL, 2007; PIMENTEL et al., 2010).

According to Nascimento Júnior et al. (2008), the $\mathrm{pH}$ of the banana tends to decrease with maturation due to the release of organic acids, mainly malic acid. Green banana pulp has a pH range of 5.05.6 whereas the mature fruit pulp has a $\mathrm{pH}$ range of 4.2-4.7 (MATSUURA; FOLEGATTI, 2001). Therefore, the variations in $\mathrm{pH}$ with fruit ripening corroborate the hypothesis that the fruit receiving the wastewater treatments $(130 \%, 170 \%$, and $200 \%$ TWW) matured unevenly compared to the control. The fact that the fruit derived from the $130 \%$, $170 \%$, and $200 \%$ TWW treatments had lower $\mathrm{pH}$ than those of the control suggests that the former were slightly more mature than the latter (Table 6). This difference may be explained by a physiological response of the banana tree to the relatively high sodium input from the TWW.

Table 6. Microbiological analysis of peel and pulp fruits of 'Prata-Anã' banana in two production cycles and different times after treated sanitary wastewater fertigation.

\begin{tabular}{|c|c|c|c|c|c|c|c|c|}
\hline \multicolumn{9}{|c|}{ First Cycle } \\
\hline \multirow{3}{*}{ Treatment } & \multicolumn{4}{|c|}{$-30 \mathrm{DAF}-$} & \multicolumn{4}{|c|}{$-45 \mathrm{DAF}-$} \\
\hline & \multicolumn{2}{|c|}{$\begin{array}{c}\text { TC } \\
\text { MPN } \text { g }^{-1}\end{array}$} & \multicolumn{2}{|c|}{$\begin{array}{c}\text { TtC } \\
\text { MPN } \text { g }^{-1}\end{array}$} & \multicolumn{2}{|c|}{$\begin{array}{c}\text { TC } \\
\text { MPN g } \text { g }^{-1}\end{array}$} & \multicolumn{2}{|c|}{$\begin{array}{c}\text { TtC } \\
\text { MPN } g^{-1}\end{array}$} \\
\hline & Peel & Pulp & Peel & Pulp & Peel & Pulp & Peel & Pulp \\
\hline Control & $<3$ & $<3$ & $<3$ & $<3$ & 23 & $<3$ & 9.2 & $<3$ \\
\hline 70 & $<3$ & $<3$ & $<3$ & $<3$ & $<3$ & $<3$ & $<3$ & $<3$ \\
\hline 130 & $<3$ & $<3$ & $<3$ & $<3$ & $<3$ & $<3$ & $<3$ & $<3$ \\
\hline 170 & $<3$ & $<3$ & $<3$ & $<3$ & $<3$ & $<3$ & $<3$ & $<3$ \\
\hline 200 & $<3$ & $<3$ & $<3$ & $<3$ & $<3$ & $<3$ & $<3$ & $<3$ \\
\hline \multicolumn{9}{|c|}{ Second Cycle } \\
\hline \multirow{3}{*}{ Treatment } & \multicolumn{4}{|c|}{ Sampling 1- } & \multicolumn{4}{|c|}{ Sampling 2- } \\
\hline & \multicolumn{2}{|c|}{$\begin{array}{c}\text { TC } \\
\text { MPN } \mathbf{g}^{-1}\end{array}$} & \multicolumn{2}{|c|}{$\begin{array}{c}\text { TtC } \\
\text { MPN } \text { g }^{-1}\end{array}$} & \multicolumn{2}{|c|}{$\begin{array}{c}\text { TC } \\
\text { MPN } \text { g }^{-1}\end{array}$} & \multicolumn{2}{|c|}{$\begin{array}{c}\text { TtC } \\
\text { MPN } \mathbf{g}^{-1}\end{array}$} \\
\hline & Peel & Pulp & Peel & Pulp & Peel & Pulp & Peel & Pulp \\
\hline Control & $<3$ & $<3$ & $<3$ & $<3$ & 23 & $<3$ & 9.2 & $<3$ \\
\hline 70 & $<3$ & $<3$ & $<3$ & $<3$ & $<3$ & $<3$ & $<3$ & $<3$ \\
\hline 130 & $<3$ & $<3$ & $<3$ & $<3$ & $<3$ & $<3$ & $<3$ & $<3$ \\
\hline 170 & $<3$ & $<3$ & $<3$ & $<3$ & $<3$ & $<3$ & $<3$ & $<3$ \\
\hline 200 & $<3$ & $<3$ & $<3$ & $<3$ & $<3$ & $<3$ & $<3$ & $<3$ \\
\hline
\end{tabular}

MPN: most probable number; TC: Total coliforms; TtC: thermotolerant coliforms; DAF: days after fertigation.

Soares (2006) verified that the cultivar 'PrataAnã' irrigated with water of $1.66 \mathrm{dS} \mathrm{m}^{-1}$ electrical conductivity (EC) developed precociously relative to plants irrigated with water of $0.31 \mathrm{dS} \mathrm{m}^{-1} \mathrm{EC}$. In the present study, the average electrical conductivity of the wastewater was $1.128 \mathrm{dS} \mathrm{m}^{-1}$ (Table 2). Soares et al. (2011) point out, however, that the banana tree may accumulate sodium in its rhizome to protect the other organs from sodium intoxication. 
The titratable acidity (AT) and the soluble solid:titratable acidity ratio (SST:AT) in both crop cycles were significantly affected by all TWW treatments and corroborated the values reported by Jesus et al. (2004).

Despite the differences in post-harvest quality observed in this study, crop productivity was similar for all treatments and both crop cycles. The average yield was $26.32 \mathrm{t} \mathrm{ha}^{-1}$ in the first cycle and $33.81 \mathrm{t}$ $\mathrm{ha}^{-1}$ in the second (ALVES, 2014).

In the first crop cycle, no contamination by total coliforms and/or thermotolerant coliforms was observed in the peel or pulp for any of the evaluated treatments (Table 6). The suspension of wastewater fertigation $30 \mathrm{~d}$ and $45 \mathrm{~d}$ before harvest may explain the lack of coliforms. Even if some microbial fruit contamination did occur during wastewater fertigation under the conditions of this study, the fertigation-free time interval may have sufficed to eliminate total and thermotolerant coliforms.

According to Sousa et al. (2006), the survival of pathogens on crop surfaces depends on environmental factors such as sunlight, temperature, and relative humidity. The author also emphasizes that, in general, these conditions are unfavorable to pathogen proliferation.

In the second crop cycle, microbial analyses were performed $24 \mathrm{~h}$ after wastewater fertigation. The sampling performed on 06/11/2014 showed that contamination with thermotolerant coliforms and E. coli was detected in the banana peel from the control treatment (Table 6).

According to Sarria and Filgueiras (2006), contamination may occur at harvest and postharvest due to improper handling, domestic animals, conveyor belts, wash water, quick-cooling water, harvest packaging, commercializing packaging, pallets, trucks, and improper handling. Based on this information, it is believed that the contaminants found in the control sample peels may be accounted for by the presence of birds and bats frequently found in the experimental area and on or near the bunches (Figure 2). Nevertheless, the contamination levels detected are in accordance with the standards established by ANVISA (2001), namely, $500 \mathrm{MPN} / \mathrm{g}$ thermotolerant coliforms in fruit samples.

Figure 2. A) Bats in banana leaves (circled) and; B) Bat droppings on fallen leaves (arrows) under the same banana plant fertigated with treated sanitary wastewater, Janaúba county, Minas Gerais State.

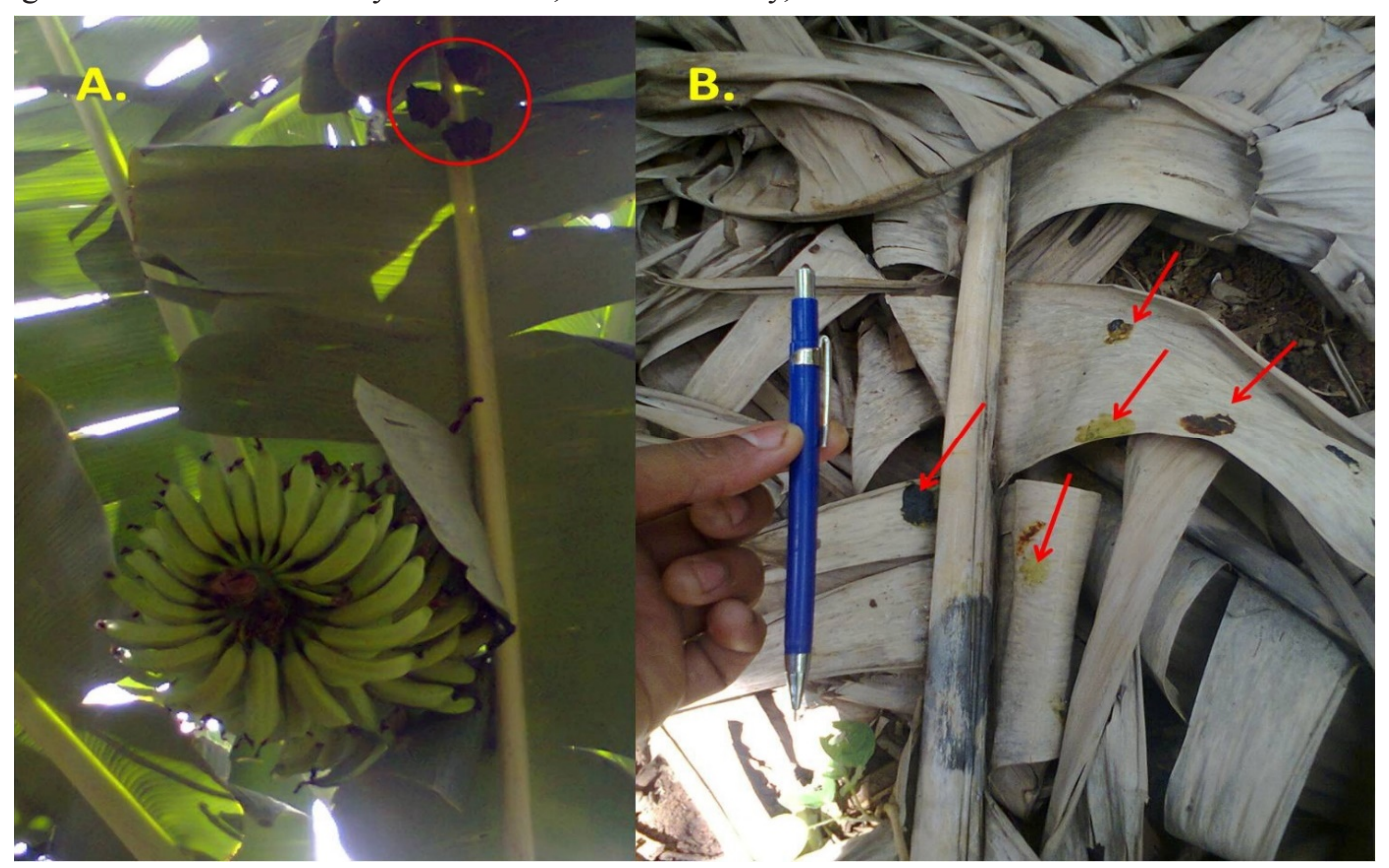


Rodrigues et al. (2013) found 5.4-35.1 g $\mathrm{g}^{-1}$ total coliforms and $<3-26.3 \mathrm{~g}^{-1}$ thermotolerant coliforms in banana peel irrigated with water from irrigation channels and tubular wells in the North-Mineira region. These contamination levels, however, were verified not at harvest but during washing of the fruits with contaminated water.

In the present work, banana fruits were harvested in such a way as to avoid any contamination other than that which would result from the wastewater treatments themselves. The fruits to be analyzed were collected on the plant to avoid soil contact, and clean gloves were worn during the sampling. The bananas were not washed and no products were applied to them in the field at the time of harvest. Additional measures were taken to avoid crosscontamination at harvest, during transport to the laboratory, and during the analyses. The microsprinkler fertigation system proved to be highly efficient because it avoided direct contact of the sanitary effluent with the fruit and minimized the risk of contamination.

\section{Conclusions}

Banana tree fertigation with treated sanitary wastewater from the Janaúba-MG STS produced fruit with a post-harvest quality similar to those derived from banana trees treated with mineral fertilizers and clean water. Nevertheless, very high doses of treated sanitary wastewater may impair nutritional balance and fruit quality.

Fertigation of banana trees with treated sanitary wastewater also results in fruit whose microbiological quality resembles that obtained by fertigation with clean water and mineral fertilizers.

\section{Acknowledgements}

The authors would like to thank the following for their financial support: the Minas Gerais
Sanitation Company, Banco do Nordeste, the State of Minas Gerais Research Foundation (FAPEMIG), the Coordination for the Improvement of Higher Education Personnel (CAPES), and the National Council for Scientific and Technological Development (CNPq).

\section{References}

AGÊNCIANACIONAL DE VIGILÂNCIA SANITÁRIA - ANVISA. Resolução RDC $\mathrm{n}^{\circ} 12$, de 02 de janeiro de 2001. Diário Oficial [da] União, Brasília, 02 jan. 2001, Seção 1, p. 46-53.

AL-LAHHAM, O.; ASSI, A. M. E.; FAYYAD, M. Impact of treated wastewater irrigation on quality attributes and contamination of tomato fruit. Agricultural Water Management, Amsterdam, v. 61, n. 1, p. 51-62, 2003.

ALLEN, R. G.; PRUITT, W. O.; WRIGHT, J. L. A recommendation on standardized surface resistance for hourly calculation of reference ETo by the FAO56 Penman-Monteith method. Agricultural Water Management, Amsterdam, v. 81, n. 1-2, p. 1-22, 2006.

ALVES, P. F. S. Fertirrigação da bananeira com água residuária sanitária tratada. 2014. Dissertação (Mestrado em Produção Vegetal no Semiárido) - Universidade Estadual de Montes Claros, Janaúba.

APHA - AMERICAN PUBLIC HEALTH ASSOCIATION; AWWA - AMERICAN WATER WORKS ASSOCIATION; WEF - WATER ENVIRONMENT FEDERATION. Standard methods for the examination of water and wastewater. $22^{\text {nd }} \mathrm{ed}$. Washington: American Public Health Association, 2012. $1360 \mathrm{p}$.

ASSOCIATION OF OFFICIAL ANALYTICAL CHEMISTRY - AOAC. Official methods of analysis of AOAC International. $19^{\text {th }}$ ed. Gaithersburg: AOAC International, 2012. $3000 \mathrm{p}$.

BARKER, S. F.; AMOAH, P.; DRECHSEL, P. A probabilistic model of gastroenteritis risks associated with consumption of street food salads in Kumasi, Ghana: evaluation of methods to estimate pathogen dose from water, produce or food quality. Science of The Total Environment, Amsterdam, v. 487, p. 130-142, 2014.

BLEINROTH, E. W.; SIGRIST, J.; ARDITO, E. de F.; CASTRO, J. de; SPAGNOL, W. Tecnologia de póscolheita de frutas tropicais. 2. ed. Campinas: ITAL, 1992. $203 \mathrm{p}$. 
CHITARRA, M. I. F.; CHITARRA, A. B. Pós-colheita de frutas e hortaliças: fisiologia e manuseio. Lavras: Universidade Federal de Lavras, 2005. 785 p.

EMPRESA BRASILEIRA DE PESQUISA AGROPECUÁRIA - EMBRAPA. Centro Nacional de Pesquisa de Solos. Sistema brasileiro de classificação de solos. 3.ed. rev. e ampl. Brasília: Embrapa, 2013. 353 p.

Embrapa Mandioca e Fruticultura. Sistema de Produção. Brasília: Embrapa, jul. 2009. Disponível em: $\quad<$ http://sistemasdeproducao.cnptia.embrapa.br/ FontesHTML/Banana/BananeiraIrrigada/adubacao. htm>. Acesso em: 22 jul. 2014.

JESUS, S. C. de; FOLEGATTI, M. I. da S.; MATSUURA, F. C. A. U.; CARDOSO, R. L. Caracterização física e química de frutos de diferentes genótipos de bananeira. Bragantia, Campinas, v. 63, n. 3, p. 315-323, 2004.

LARCHER, W. Ecofisiologia vegetal. São Carlos: RIMA Artes e Textos, 2005. $550 \mathrm{p}$.

MAIA, V. M.; SALOMÃO, L. C. C.; CANTARUTTI, R. B.; VENEGAS, V. H. A.; COUTO, F. A. D. Efeitos de dose de nitrogênio, fósforo e potássio sobre os componentes da produção e a qualidade de bananas Prata Anã no distrito agroindustrial de Jaíba. Revista Brasileira de Fruticultura, Jaboticabal, v. 25, n. 2, p. 319-322, 2003.

MANTOVANI, E. C.; BERNARDO, S.; PALARETTI, L. F. Irrigação: princípios e métodos. 3. ed. Viçosa-MG: UFV, 2009. 355 p.

MATSUURA, F. C. A. U.; FOLEGATTI, M. I. S. Banana pós-colheita. Brasília: Embrapa Mandioca e Fruticultura, $2001.71 \mathrm{p}$.

METCALF, I.; EDDY, H. Wastewater engineering; treatment and reuse. $4^{\text {th }}$ ed. New York: McGraw-Hill Book, 2003.1815 p.

NASCIMENTO JÚNIOR, B. B.; OZORIO, L. P.; REZENDE, C. M.; SOARES, A. G.; FONSECA, M. J. de O. Diferenças entre bananas de cultivares Prata e Nanicão ao longo do amadurecimento: características físicoquímicas e compostos voláteis. Ciência e Tecnologia de Alimentos, Campinas, v. 28, n. 3, p. 649-658, 2008.

OLIVEIRA, S. L. de; BORGES, A. L.; COELHO, E. F.; COELHO FILHO, M. A.; SILVA, J. T. A. Uso da irrigação e da fertirrigação na produção integrada de banana no Norte de Minas Gerais. Cruz das Almas: EMBRAPA, 2005. 7 p. (Circular técnica, 77).

PAGANINI, W. S. Reúso de água na agricultura. In: MANCUSO, C. S. A.; SANTOS, H. F. (Ed.). Reúso de água. Barueri: Manole, 2003. p. 339-401.

$\begin{array}{llcc}\text { PROGRAMA } & \text { BRASILEIRO } & \text { PARA } & \text { A } \\ \text { MODERNIZAÇÃO } & \text { DA } & \text { HORTICULTURA } & \&\end{array}$

PRODUÇÃO INTEGRADA DE FRUTAS - PBMH; PIF. Normas de classificação de banana. São Paulo: CEAGESP, 2006.

PIMENTEL， R. M. de A.; GUIMARÃES, F. N.; SANTOS, V. M. dos; RESENDE, J. C. F. de. Qualidade pós-colheita dos genótipos de banana PA42-44 e PrataAnã cultivados no norte de Minas Gerais. Revista Brasileira de Fruticultura, Jaboticabal, v. 32, n. 2, p. 407-413, 2010.

RODRIGUES, F. B.; MIZOBUTSI, E. H.; MIZOBUTSI, G. P.; FERREIRA RIBEIRO, R. C.; VELOSO, J. S. Análise microbiológica de banana Prata-Anã produzida no norte de Minas Gerais. Bioscience Journal, Uberlândia, v. 29, n. 4, p. 826-832, 2013.

SARRIA, S. D.; FILGUEIRAS, H. A. C. Contaminações biológica e química. In: OLIVEIRA, S. M. A; TERAO, D.; DANTAS, S. A. F.; TAVARES, S. C. C. H. Patologia pós-colheita: frutas, olerícolas e ornamentais tropicais. Brasília: EMBRAPA Informação Tecnológica, 2006. p. 387-409.

SCANDOLERA, A. J.; PALHARES, J. C.; LUCAS JUNIOR, J.; AMARAL, L. A. do; MENDONÇA, R. P. de; OLIVEIRA, G. P. de. Avaliação de parâmetros químicos, microbiológicos e parasitológicos de águas de abastecimento da UNESP e residuária, no município de Jaboticabal, Estado de São Paulo. Semina: Ciências Agrárias, Londrina, v. 22, n. 1, p. 83-91, 2001.

SHUVAL, H.; LAMPERT, Y.; FATTAL, B. Development of a risk assessment approach for evaluating wastewater reuse standards for agriculture. Water Science and Technology, Oxford, v. 35, n. 11-12, p. 15-20, 1997.

SILVA, J. T. A.; BORGES, A. L.; MALBURG, J. L. Solos, adubação e nutrição da bananeira. Informe Agropecuário, Belo Horizonte, v. 20, n. 196, p. 21-36, 1999.

SILVA, N.; CANTUSIO NETO, R.; JUNQUEIRA, V. C. A.; ARRUDA SILVEIRA, N. F. Manual de métodos de análise microbiológica de alimentos e água. 4. ed. São Paulo: Varela, 2010. 614 p.

SOARES, F. A. L. Crescimento, nutrição mineral e produção de bananeiras irrigadas com águas de salinidades diferentes. 2006. Tese (Doutorado em Engenharia Agrícola) - Universidade Federal de Campina Grande, Campina Grande.

SOARES, F. A.; ALVES, A. N.; GHEYI, H. R.; UYEDA, C. A. Acúmulo de matéria seca e distribuição de nutrientes em duas cultivares de bananeiras irrigadas com água moderadamente salina. Revista Brasileira de Ciências Agrárias, Recife, v. 6, n. 2, p. 321-330, 2011.

A SOUSA, J. T. de; CEBALLOS, B. S. O. de; HENRIQUE, \& I. N.; DANTAS, J. P.; LIMA, S. M. S. Reúso de água 
residuária na produção de pimentão (Capsicum annuum L.). Revista Brasileira de Engenharia Agrícola e Ambiental, Campina Grande, v. 10, n. 1, p. 89-96, 2006.

SPIRONELLO, A.; QUAGGIO, J. A.; TEIXEIRA, L. A. J.; FURLANI, P. R.; SIGRIST, J. M. M. Pineapple yield and fruit quality effected by NPK fertilization in a tropical soil. Revista Brasileira de Fruticultura, Jaboticabal, v. 26, n. 1, p. 155-159, 2004.

VIVIANI, L.; LEAL, P. M. Qualidade pós-colheita de banana Prata Anã armazenada sob diferentes condições. Revista Brasileira de Fruticultura, Jaboticabal, v. 29, n. 3, p. 465-470, 2007.
VUGIA, D.; HADLER, J.; CHAVES, S.; BLYTHE, D.; SMITH, K.; MORSE, D.; CIESLAK, P.; JONES, T.; CRONQUIST, A.; GOLDMAN, D. Preliminary foodnet data on the incidence of foodborne illnesses-Selected sites, United States. 2001. CDC, Morbidity and Mortality Weekley Report, Atlanta, v. 51, n. 15, p. 325-329, 2002.

WEBER, O. B.; MONTENEGRO, A. A. T.; SILVA, Í. M. N. E.; SOARES, I.; CRISÓSTOMO, L. A. Adubação nitrogenada e potássica em bananeira Pacovan (musa AAB, subgrupo prata) na chapada do Apodi, Estado do Ceará. Revista Brasileira de Fruticultura, Jaboticabal, v. 28, n. 1, p. 154-157, 2006. 